\title{
MAAMME PERUNALAJIKKEIDEN VILJELYLAAJUUS JA VILJELYALUEET
}

\author{
P. J. SAKSA \\ Maataloushallituksen tilastotoimisto, Helsinki \\ Saapunut 16. 11. 1954 .
}

Vuoden 1950 yleiseen maatalouslaskentaan liittyvän satotiedustelun yhteydessä, mikä toimeenpantiin po. vuoden lopulla, kerättiin tietoja myös perunalajikkeiden viljelylaajuuden ja viljelyalueiden selvittämiseksi. Tiedot koottiin ns. tilastoviljelmiltä, jotka oli valittu arpomalla viljelmänsuuruusluokittain. Tämän menetelmän periaatteet ovat tulleet selostetuiksi jo aikaisemmin toisessa yhteydessä $(2,3)$.

Mainittakoon, ettei Suomessa ole aikaisemmin suoritettu tilastollista tutkimusta perunalajikkeiden viljelylaajuuksista. Nyt käsillä oleva tutkimus perustuu viljelijöiden itsensä antamiin lajiketietoihin. Näinollen sen antama tulos ei voi olla täysin luotettava. Erityisesti perunan kohdalla on lajikkeiden lukumäärä niin suuri ja eri lajikkeet siinä määrin toisiinsa sekoittuneet, etteivät viljelijät kaikissa tapauksissa tiedä, mitä lajiketta heidän viljelemänsä peruna on. Ruotsissa vuonna 1937 aloitettu, koko maata koskeva perunalajikkeiden viljelylaajuustutkimus (1) suoritettiin osittain toisin perustein kuin tässä selostettavana oleva, joka pohjautuu vain kyselyihin. Tietojen kerääminen Ruotsissa samoinkuin meilläkin suoritetussa tutkimuksessa tapahtui edustavuusnäkökohdat huomioonottaen määrätyn otantamenetelmän mukaisesti. Ruotsalaiseen tutkimukseen liittyi kuitenkin 11000 lajikenäytteen kerääminen. Näytteet istutettiin ja vasta kasvustojen perusteella määritettiin kustakin näytteestä esiintyvä tai esiintyvät lajikkeet. Näin meneteltiin, jotta olisi vältytty lajikkeiden tuntemattomuudesta johtuvista virheistä. Aitousmääritys osoitti, että kaikista tutkituista näytteistä oli lajikepuhtaita vain $48 \%$. Kahden tai useamman lajikkeen muodostamia näytteitä oli siis $52 \%$. Näytteiden ottajat olivat lähettäneet tuntemattomina tai väärällä lajikenimellä $41 \%$ kaikista näytteistä. Nämä Ruotsissa suoritetun tutkimuksen tulokset antavat aiheen otaksua, ettei suuri osa viljelijöistä meilläkään tiedä viljelemänsä perunalajikkeen nimeä. Tosin lajikekirjavuus lienee Ruotsissa huomattavasti suurempi kuin meillä, sillä edellämainitussa tutkimuksessa eri lajikkeita tuli esille 220 . 
Viljelijöiden keskuudessa suoritettu tiedustelu ei ilmeisesti anna nimenomaan perunalajikkeiden viljelylaajuudesta tarkalleen oikeata kuvaa. Selvittämättömien tapausten luku saattaa nimittäin jäädä huomattavan suureksi. Kun meillä kerättiin tiedot noin 17000 viljelmältä niiden kesällä 1950 käyttämistä perunalajikkeista, jäi näiden viljelmien peruna-alasta melko tarkoin $1 / 3$ eli $33.2 \%$ sellaiseksi alaksi, jolla ilmoitusten mukaan ei joko voitu lajiketta määrittää tai olivat lajikkeet epäpuhtaita tai sekoituksia. Pienillä viljelmillä oli \%-luku huomattavasti suurempi kuin suuremmilla viljelmillä $(2.00-4.99$ ha:n viljelmillä $48.1 \%$, yli 25 ha:n viljelmillä $18.0 \%$ ). Näihin lukuihin sisältyvät myös sellaiset nimikkeet kuin maatiaiset ja muut selvitetyt, mutta vain vähän esiintyneet lajikkeet.

Kuitenkin voimme todeta, että tilastollisellakin tiedustelulla ilman kentällä tapahtuvaa lajikepuhtausmääritystä saadut tulokset antavat tyydyttävän selvityksen eri perunalajikkeiden viljelylaajuussuhteista. Huomattakoon, että tällainen tiedustelu on erittäin halpa ja myöskin nopea suorittaa. Näin ollen sillä on merkittäviä etuja muihin lajikkeiden viljelylaajuutta selvitteleviin tutkimusmenetelmiin nähden. Ruotsissa toimeenpannun tutkimuksen kustannukset ovat todennäköisesti olleet melkoiset, sillä kenttätyö kesti yksistään 7 vuotta ja tulosten julkaiseminen tapahtui vasta 14 vuotta inventoinnin alkamisen jälkeen. Tutkimuksen antama tulos menettää paljon merkityksestään sen kautta, että perunalajikkeisto saattaa tutkimuksen kestäessä huomattavasti muuttua. Tarkoituksena on, että Suomessa toimeenpantaisiin lajiketutkimuksia vuositiedustelujen yhteydessä joka viides vuosi, jolloin tulokset saadaan neuvontahenkilöstön käyttöön jo seuraavana vuonna. Jos neuvojakunnalla on käytettävänään tiedot lajikkeiden levinneisyydestä ja samalla uusimpien lajikkeiden viljelyarvosta, voidaan kehitystä tarkoituksellisesti ohjata toivottuun suuntaan ja siten vähitellen päästä eroon heikkosatoisista, huonolaatuisista ja sekaantuneista lajikkeista, joiden kauppa- ja käyttöarvo on yleensä heikko. Tätä päämäärää tavoiteltaessa on suuri merkitys nopeasti suoritetulla ja halvalla tilastotiedustelulla, joka käytettävissä olevin keinoin pyrkii mahdollisimman suureen luotettavuuteen.

Tiedustelussa kertyneen ensiaineiston käsittelyssä noudatettiin yleisesti omaksuttua järjestystä, joka on seuraava:

a. aineiston asiallinen tarkastus ja numerointi,

b. taulukointi,

c. suhdekertoimien ja lopputulosten laskeminen,

d. tulosten erittely.

Ennenkuin voitiin ryhtyä näihin tehtäviin, oli laadittava lajikeluettelo sen mukaan, miten eri lajikkeita näytti aineistossa esiintyvän. Lajikkeiden järjestyksessä ei luonnollisestikaan voitu noudattaa minkäänlaista yleisyysjärjestystä. Myöskään ei luetteloon sisällytetty kaikkia mahdollisesti esiintyviä lajikkeita, vaan vietiin harvoin esiintyvät lajikkeet ryhmään "muut». Samasta lajikkeesta käytetyt, useasti kansanomaiset tai paikkakunnalliset nimitykset yritettiin eliminoida pois merkitsemällä ne samalla tunnusnumerolla, kuten esimerkiksi Eigenheimer, Lapuan Niku, Niku, Teiskon Eino jne. Aina ei tällöinkään voitu ratkaista oikeata tunnus- 
numeroa, jolloin esimerkiksi lajikenimitykset saksalainen, hollantilainen, venäläinen, saaristolainen, jne. vietiin ryhmään "muut». Lajikeluettelo muodostui kokonaisuudessaan seuraavaksi:

Alfa, Ben Lomond, Bintje, Deodara, Eigenheimer (eli Lapuan Niku, Niku, Teiskon Eino), Eldorado (eli Evergood, Immergut), Frühgold, Heinäkuu (eli Juli), Iso skotlantilainen (eli Great Scot), Kuningas Yrjö (eli King George V) Laivaperuna (eli Obenwälder Blaue), Magnum bonum, Majestic, Nuutti (eli Frühnudel), Ostbote, Parnassia, Paulin peruna (eli Paul Wagner), Pepo, Puritaani (eli Aikainen Puritaani, Kaiserkrone, Early Puritan), Ruusu (eli Ruusuperuna, Aikainen Ruusu, Early Rose), Ruusulehti (eli Rosafolia), Siikli (eli Sieglinde), Tammiston aikainen, Upto (eli Up to date, Kuvernööri, Helmi), Vesijärvi (eli Harbinger)

sekä ryhmät: maatiaiset, sekalaiset, muut (esim. saksalainen, hollantilainen, venäläinen, saaristolainen) ja tuntemattomat.

Aineiston asiallisen tarkastuksen yhteydessä otettiin mukaan kaikki ensitiedot, jotka sisälsivät lajikemaininnan. Jos tieto lajikkeesta puuttui, ei lomakkeen mahdollisesti sisältämää korjuualaakaan otettu tutkimuksessa huomioon. Taulukointi tapahtui näinollen kunkin ryhmän (lajikkeen) kohdalla viljelyaloittain. Kun tilastoviljelmien valinta oli tapahtunut viljelmänsuuruusluokittain, oli myös tulosten laskemisessa noudatettava suuruusluokkajaoittelua ja taulukoitava tulokset ensin kussakin suuruusluokassa erikseen. Laskemalla suhdekerroin kussakin suuruusluokassa maanviljelysseuroittain ja kertomalla kunkin lajikkeen taulukointitulokset sillä ja laskemalla edelleen nämä tulemat yhteen, saatiin selville lajikkeiden yleisyys kunkin maanviljelysseuran alueella ja edelleen koko maan vastaavat luvut punnittuina keskimäärinä. Ainoa olettamus, joka oli tehtävä tätä suhdemenetelmää käytettäessä, oli se, että ne korjuualat, joilta lajike oli jäänyt jostain syystä kokonaan ilmoittamatta, jakautuivat eri lajikkeiden ja epäselvien osalle samassa suhteessa kuin muukin ala. Täten tuli otetuksi mukaan perunanviljelyn koko ala kullakin alueella ja tulokset voitiin laskea suhdelukuina koko viljelyalasta. Vaikka menettely on ilmoittamatta jätettyjen lajikkeiden osalta jossain määrin mielivaltainen, on sen virhevaikutus lopputuloksiin ilmeisesti melko vähäinen.

Seuraavassa esitetään kunkin lajikkeen viljelylaajuus maamme eri osissa alkaen eniten viljellyistä lajikkeista:

1. Ruusulehti, Rosafolia (taul. 1, piirros 1 a). Ylivoimaisesti yleisin perunalajikkeemme on Ruusulehti. Sen viljelyala on ollut $12.3 \%$ perunan koko viljelyalasta. Vaikka Ruusulehteä viljellään kautta koko maan, ovat eri alueiden väliset erot viljelylaajuudessa melkoiset, kuten voimme havaita taulukosta 1 ja sen perusteella laaditusta karttapiirroksesta 1 a. Huomattavin Ruusulehden viljelyalue on Varsinais-Suomi ja Häme, missä peruna-alasta noin 1/5 on Ruusulehteä. Myös Kaakkois-Suomessa on Ruusulehden osuus ollut lähes viidennes. Uudellamaalla, Mikkelin ja Kuopion lääneissä on sen osuus ollut yli $10 \%$, mutta muualla sen sijaan $5 \%$ :n seutuvilla tai sen alle. Huomionarvoisena seikkana on mainittava, että ruotsinkielisillä alueilla Ruusulehteä samoin kuin eräitä muitakin yleislajikkeita viljellään suhteellisen vähän, samoin Pohjanmaalla.

2. Vesijärvi, Harbinger (taul. 1, piirros 1 b). Toiseksi eniten viljelty perunalajike Suomessa on Vesijärvi. Sen viljelyala on $9.1 \%$ perunan koko viljelyalasta. Aikaisena lajikkeena se on saavuttanut 


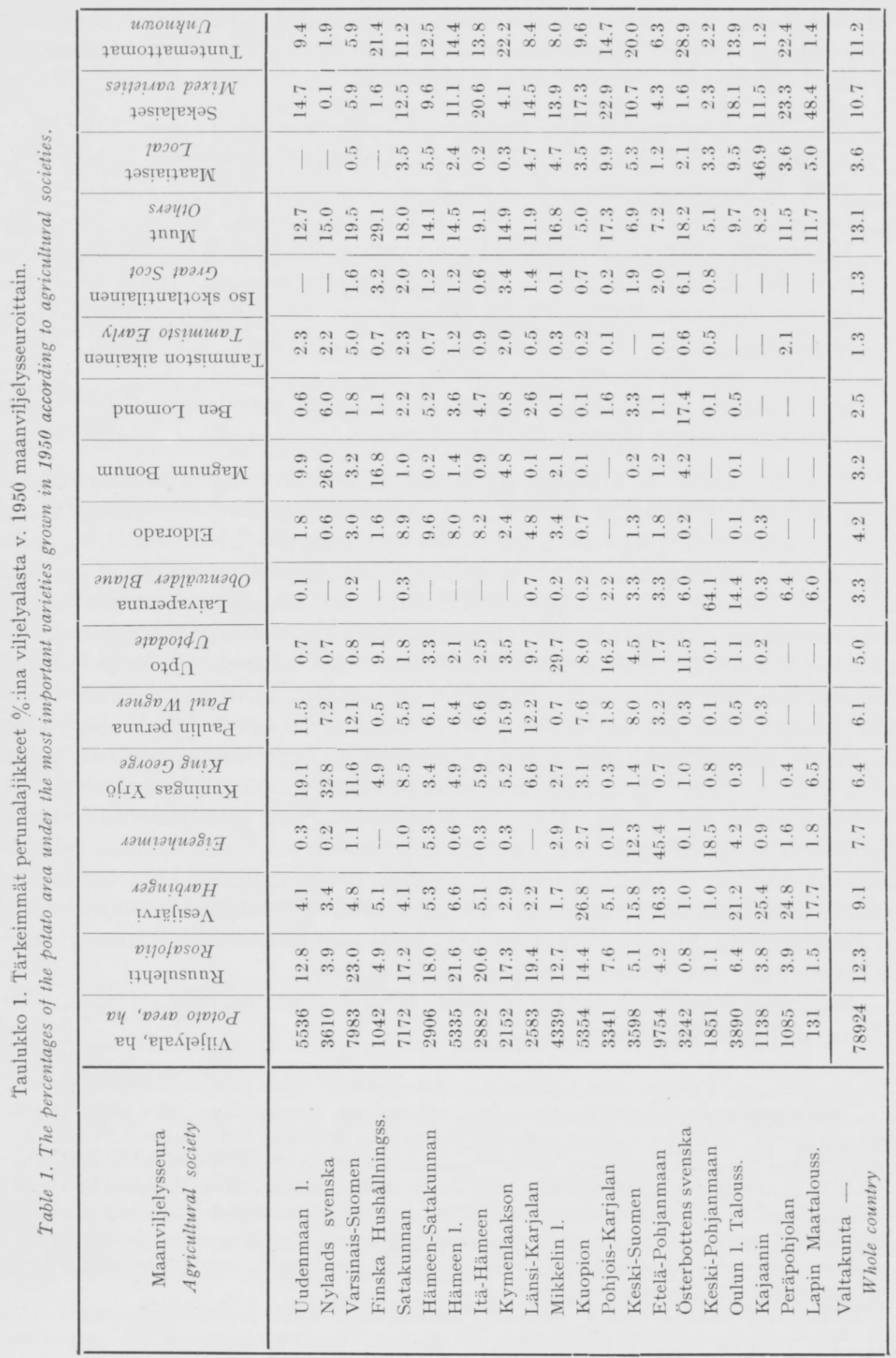


huomattavan viljelylaajuuden varsinkin maan pohjoispuoliskon perunaviljelyksillä aina Keski-Suomesta saakka. Kuopion läänissä ja Kainuussa viljellään Vesijärveä yli 1/4:lla koko peruna-alasta ja Oulun läänin Talousseuran ja Peräpohjolan maanviljelysseuran alueilla yli 1/5:lla peruna-alasta. Etelä-Pohjanmaalla, Keski-Suomessa ja Lapissa viljellään Vesijärveä keskimäärin 16 -17\% peruna-alasta.

3. Eigenheimer (taul. 1, piirros 1 c). Kolmanneksi eniten viljelty perunalajike on Eigenheimer. Sillä on varsin runsaasti kansanomaisia lajikenimiä kuten Lapuan Niku, Niku, Teiskon Eino jne. Eniten sitä viljellään Etelä-Pohjanmaalla, jossa sen hallussa on lähes puolet peruna-alasta. Myös KeskiPohjanmaalla ja Keski-Suomessa viljellään sitä melkoisen paljon. Koko maan peruna-alasta viljeltiin Eigenheimeria $7.7 \%$.

4. Kuningas Yrjö, King George $V$ (taul. 1, piirros 1 d). Kuningas Yrjöä viljellään runsaimmin maan etelä-osissa, etelä-rannikolla jopa lähes $1 / 3$ koko viljelyalasta. Uudenmaan pohjoispuoliskolla on vastaava ala lähes 1/5, Varsinais-Suomessa yli 1/10 ja Satakunnassa lähes 1/10. Hämeessä ja KaakkoisSuomessa on sen viljelyala $5-6.5 \%$ peruna-alasta. Muualla on Kuningas Yrjön viljely,vähäisempää. Koko maan peruna-alasta on käytetty Kuningas Yrjön viljelyyn $6.4 \%$.

5. Paulin peruna, Paul Wagner (taul. 1, piirros 2 a). Kolmas verraten tyypillinen Etelä-Suomen perunalajike Ruusulehden ja Kuningas Yrjön jälkeen on Paulin peruna. Varsinais-Suomessa, Uudellamaalla ja Kaakkois-Suomessa sen viljelyala on yli $10 \%$, Kymenlaaksossa jopa $15.9 \%$ perunan viljelyalasta. Satakunnassa, Hämeessä, Keski-Suomessa ja Kuopion maanviljelysseuran alueilla sitä viljellään keskimäärin 5.5-8\% peruna-alasta. Muualla on sen viljely vähäisempää. Koko maan perunaalasta on Paulin perunan hallussa $6.1 \%$.

6. Upto, Up to date, Kuvernööri, Helmi (taul. 1, piirros 2 b). Samalla tavalla kuin Eigenheimer esiintyi Pohjanmaalla tyypillisenä perunalajikkeena, esiintyy Up to date eli Upto Itä-Suomessa valtalajikkeena. Eritoten Mikkelin läänissä viljellään paljon tätä lajiketta eli lähes $1 / 3$ koko perunaalasta. Pohjois-Karjalassa on vastaava ala $16.2 \%$. Samaan viljelyalueeseen voidaan lukea vielä Kuopion ja Länsi-Karjalan maanviljelysseurojen alueet viljelyalan ollessa niillä 8 - $10 \%$. Uptoa viljellään paljon myös Pohjanmaan ruotsalaisella rannikkoalueella sekä Ahvenanmaalla ja Turun saaristossa. Muualla jää sen viljely alle $5 \%$ :n perunan koko viljelyalasta. Keskimyöhäisenä lajikkeena sitä ei viljellä Pohjois-Suomessa kuin nimeksi. Koko maan peruna-alasta on Uptolla ollut vuonna 1950 $\operatorname{tasan} 5 \%$.

7. Laivaperuna, Obenwälder Blaue (taul. 1, piirros 2 c). Laivaperunan viljelyalue rajoittuu pääasiassa Keski- ja Pohjois-Pohjanmaalle ja Lappiin. Keski-Pohjanmaalla sitä viljellään huomattavasti yli puolella perunan viljelyalasta (osuus-\% 64.1). Oulun läänin Talousseuran alueella on vastaava luku $14.4 \%$. Ilmeisesti juuri seuran länsipuoliskolla on Laivaperunan viljely yleistä. Lapissa viljellään sitä n. $6-6.5 \%$ :a perunan alasta. Koko maan osuudeksi tulee $3.3 \%$. Etelä-Suomessa ei Laivaperunaa viljellä.

8. Eldorado, Evergood, Immergut (taul. 1, piirros 2 d). Eldoradon pääviljelyalue on Satakunnan ja Hämeen maanviljelysseurojen alueilla, joilla sitä viljellään keskimäärin $8-9.5 \%$ perunan alasta. Muualla on Eldoradon viljely vähäisempää. Pohjois-Suomessa viljellään sitä vain nimeksi tai ei ensinkään, sillä se kuuluu keskimyöhäisiin lajikkeisiin. Eldoradon viljelyala on $3.2 \%$ maan peruna-alasta.

9. Magnum bonum (taul. 1, piirros 3 a). Vaikka Magnum bonumia viljellään aina Keski-Suomen korkeudelle saakka, on sen pääasiallisin viljelyalue maan etelärannikko. Jonkinverran sitä viljellään myös Pohjanmaan rannikolla. Tämä lajike, joka on Ruotsissa yleisin, on suosituin Uudenmaan ruotsalaisella alueella, jossa sitä viljellään 1/4:1la peruna-alasta, ja Ahvenanmaalla sekä Turun saaristossa, jossa sitä viljellään lähes 1/5:lla peruna-alasta. Koko maan peruna-alasta on Magnum bonumin osuus $3.2 \%$.

10. Ben Lomond (taul. 1, piirros $3 \mathrm{~b}$ ). Ben Lomondia viljellään yleisimmin eli $17.4 \%$ perunaalasta Pohjanmaan ruotsalaisella alueella. Myös Uudenmaan ruotsalaisella alueella se on verraten yleinen. Hämeessä sitä viljellään keskimäärin $3.5-5 \%$ peruna-alasta. Muualla sen viljely on vähäisempää. Koko maan peruna-alasta on Ben Lomondin osuus $2.5 \%$.

11. Tammiston aikainen (taul. 1, piirros $3 \mathrm{c}$ ), jota viljellään pääasiallisesti varhaisperunana, on levinnyt likimain yli koko maan Pohjois-Suomea lukuunottamatta. Eniten sitä viljellään VarsinaisSuomessa eli $5.0 \%$ seuran peruna-alasta. Muualla Etelä-Suomessa sen viljelyala on noin $2.0 \%$. Koko maan peruna-alasta on Tammiston aikaisen osuus $1.3 \%$. 


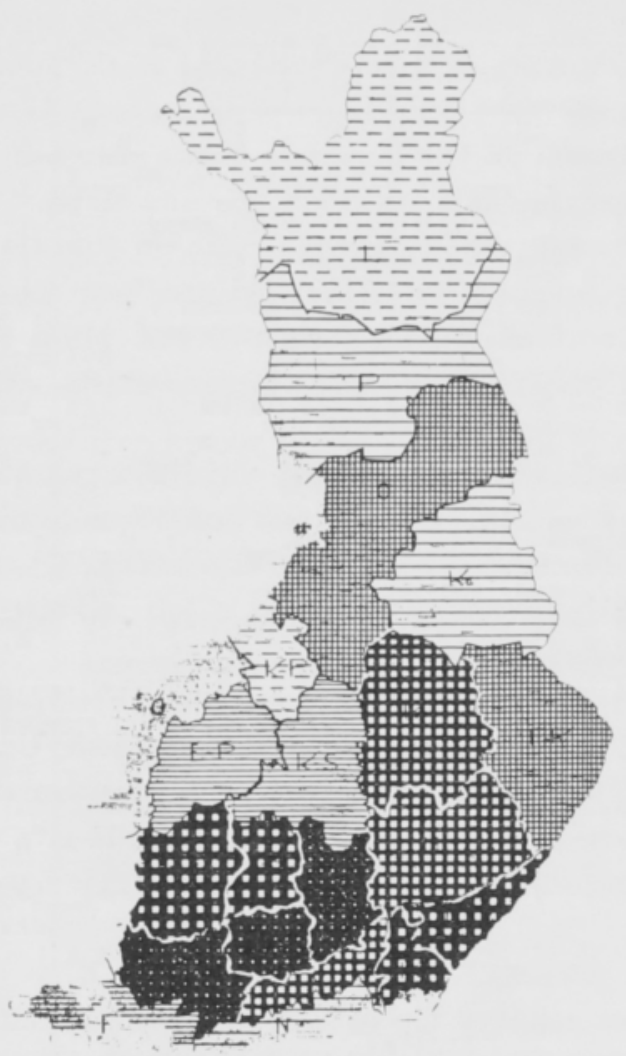

a. Ruusulehti Rosafolia

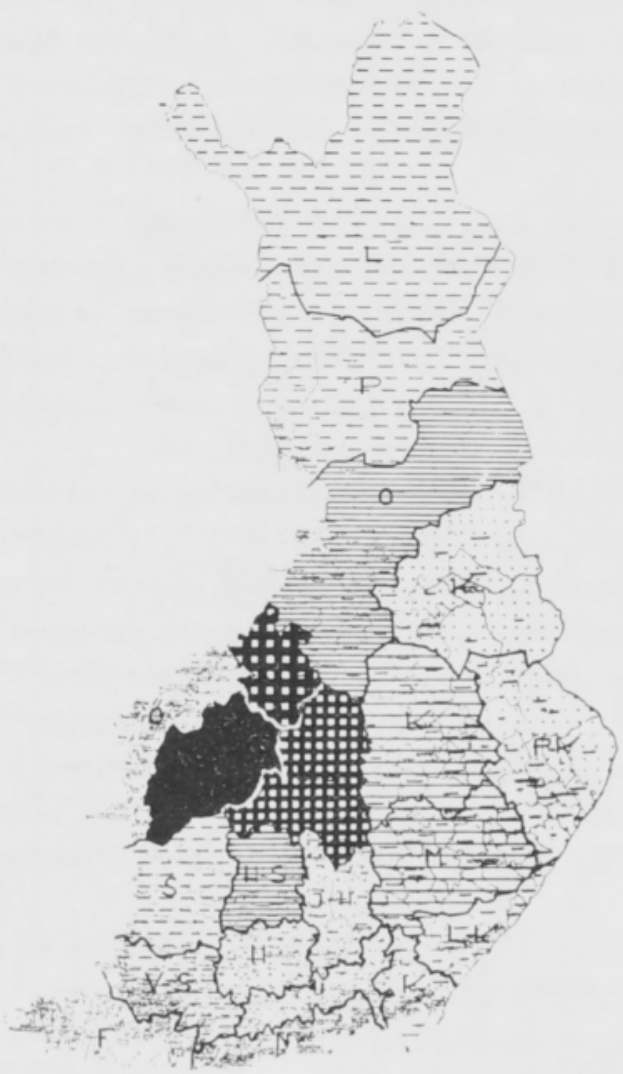

c. Eigenheimer

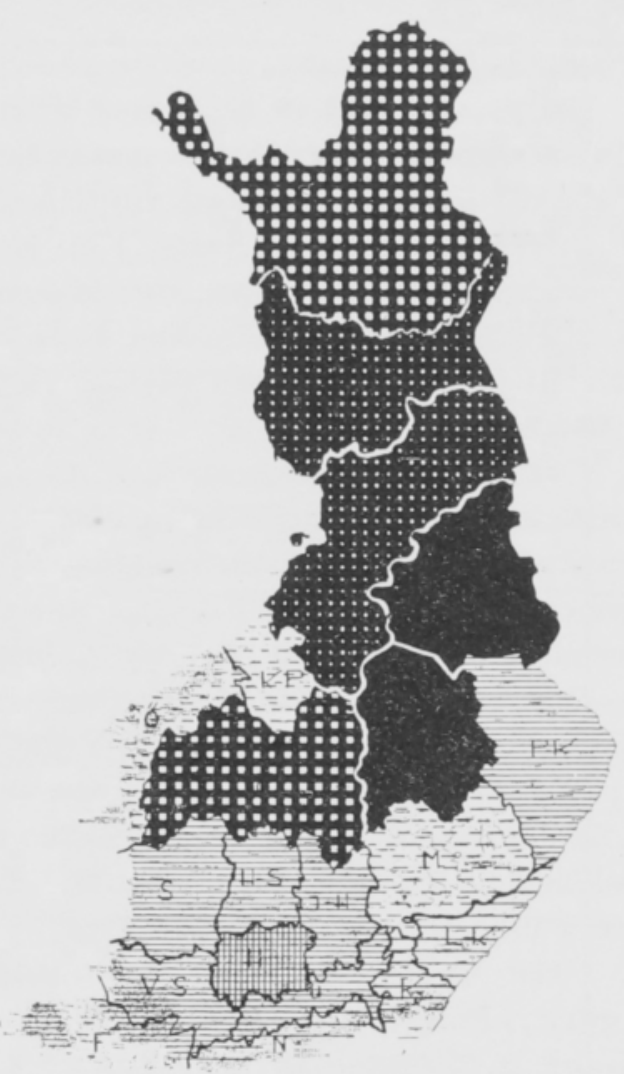

b. Vesijärvi Harbinger

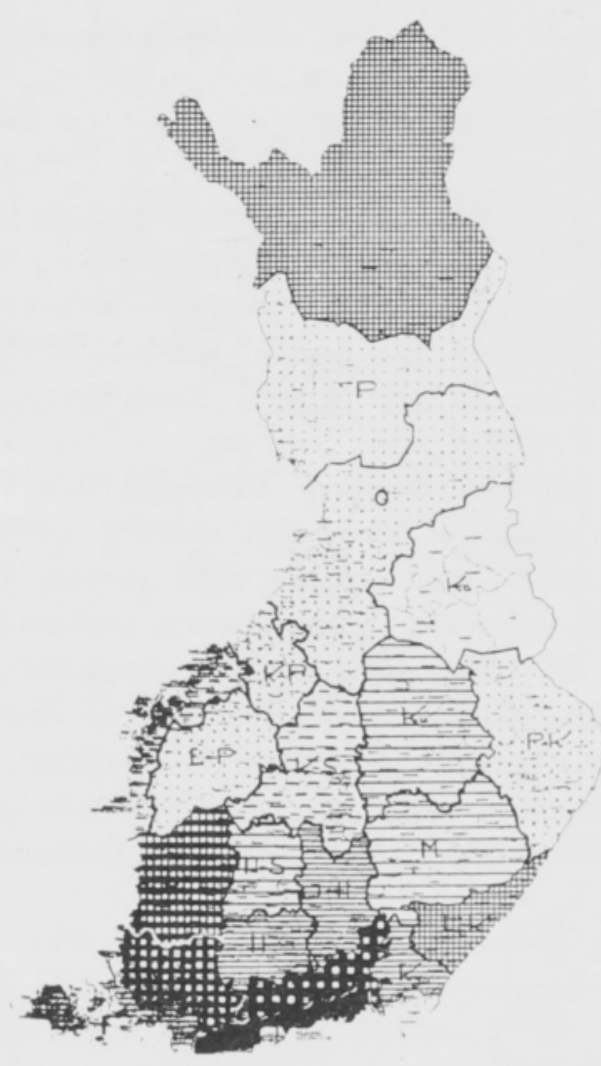

d. Kuningas Yrjö King George

Piirros 1. a) Ruusulehden, b) Vesijärven, c) Eigenheimerin ja d) Kuningas Yrjön viljelyala \%:issa perunan koko viljelyalasta maanviljelysseuroittain vuonna 1950. (Vrt. karttaselostukseen piirroksessa 4.) Fig. 1. Percentages of the potato area under varieties a) Rosafolia, $b$ ) Harbinger, c) Eigenheimer and d) King George according to agricultural societies in 1950. (Obs. the notes in the Fig. 4.) 


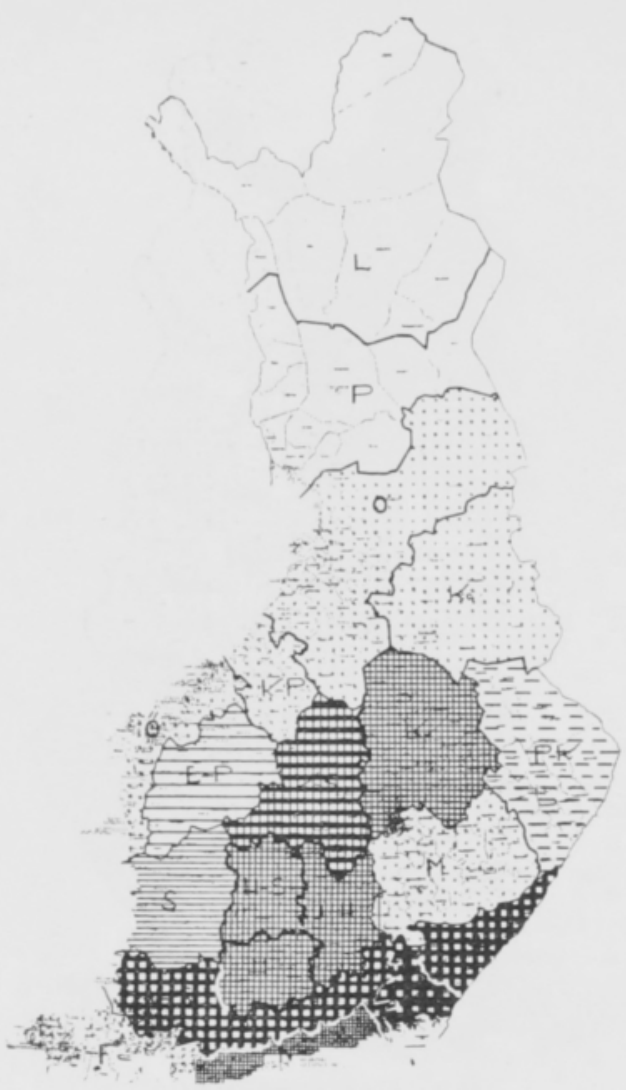

a. Paulin peruna Paul Wagner

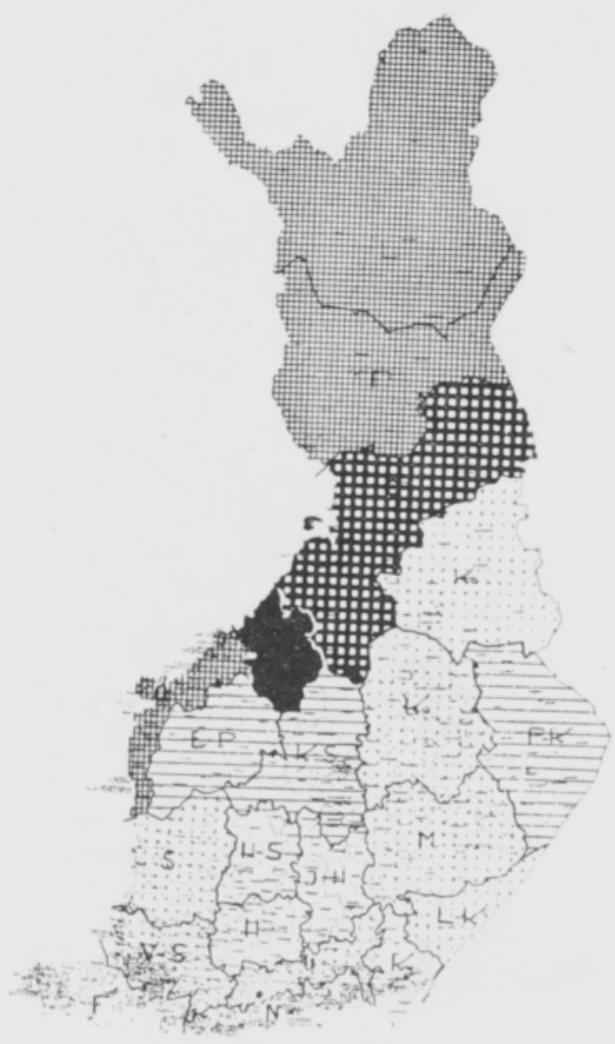

c. Laivaperuna Obenwälder Blaue

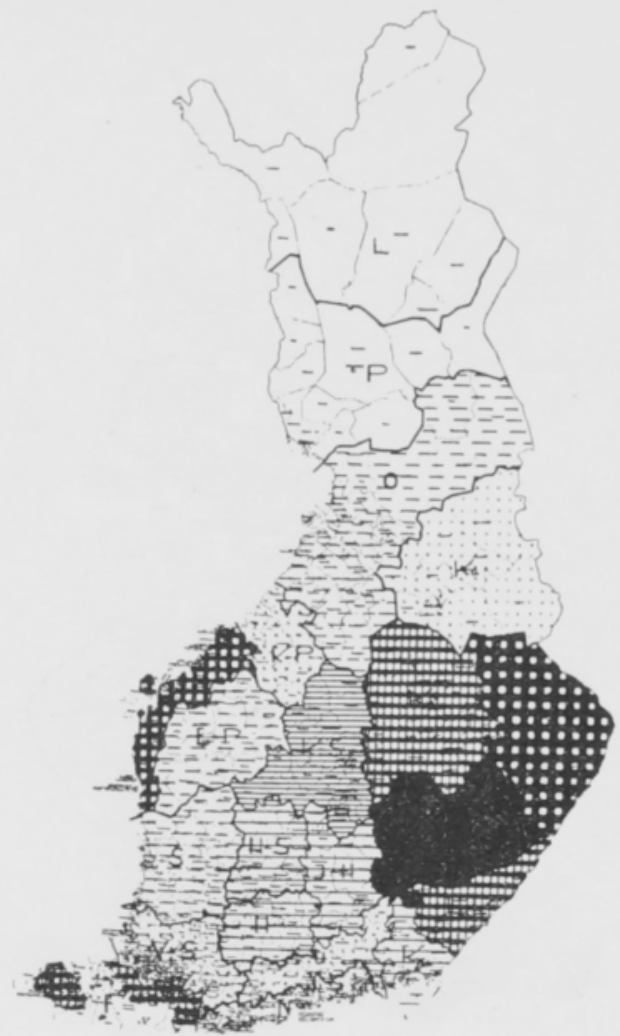

b. Upto Uptodate

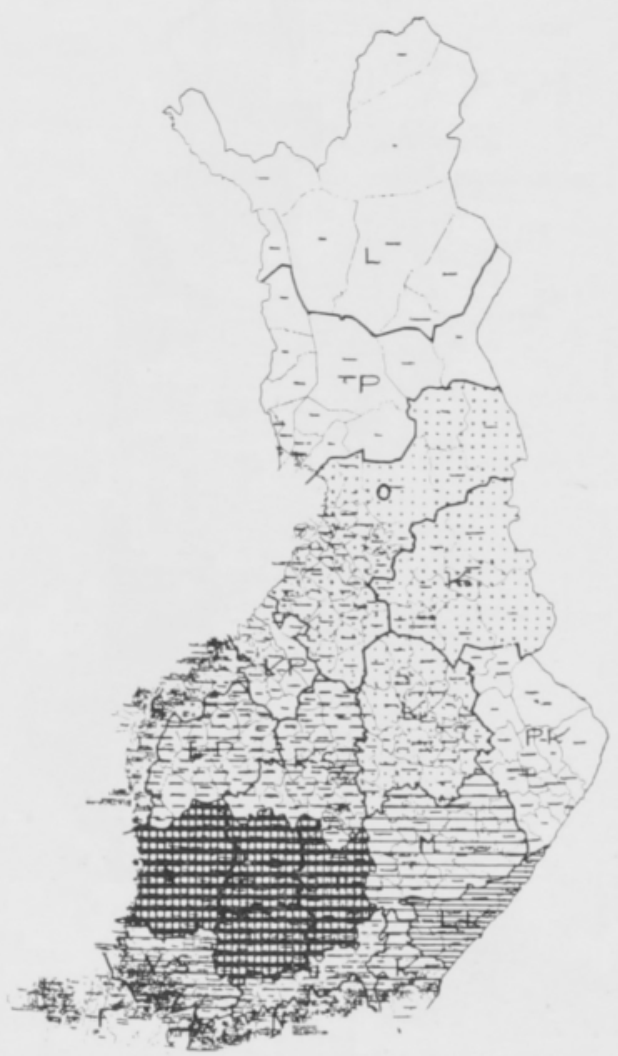

d. Eldorado

Piirros 2. a) Paulin perunan, b) Upton, c) Laivaperunan ja d) Eldoradon viljelyalat \%:issa perunan koko viljelyalasta maanviljelysseuroittain vuonna 1950. (Vrt. karttaselostukseen piirroksessa 4.) Fig. 2. Percentages of the potato area under varieties a) Paul Wagner, b) Uptodate, c) Obenwälder Blaue and d) Eldorado according to agricultural societies in 1950. (Obs. the notes in the Fig. 4.) 


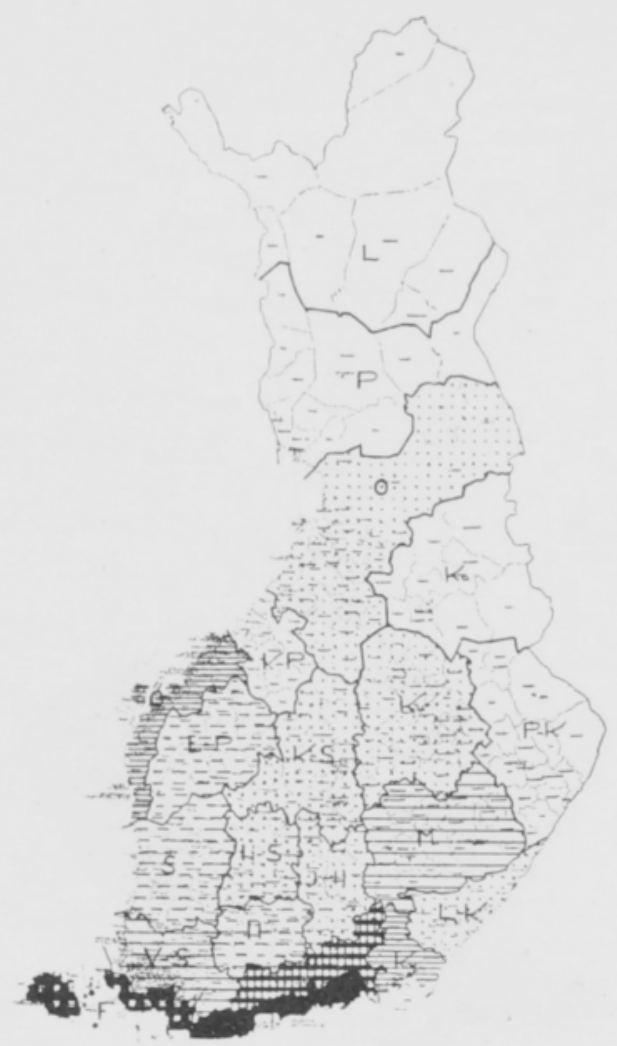

a. Magnum bonum

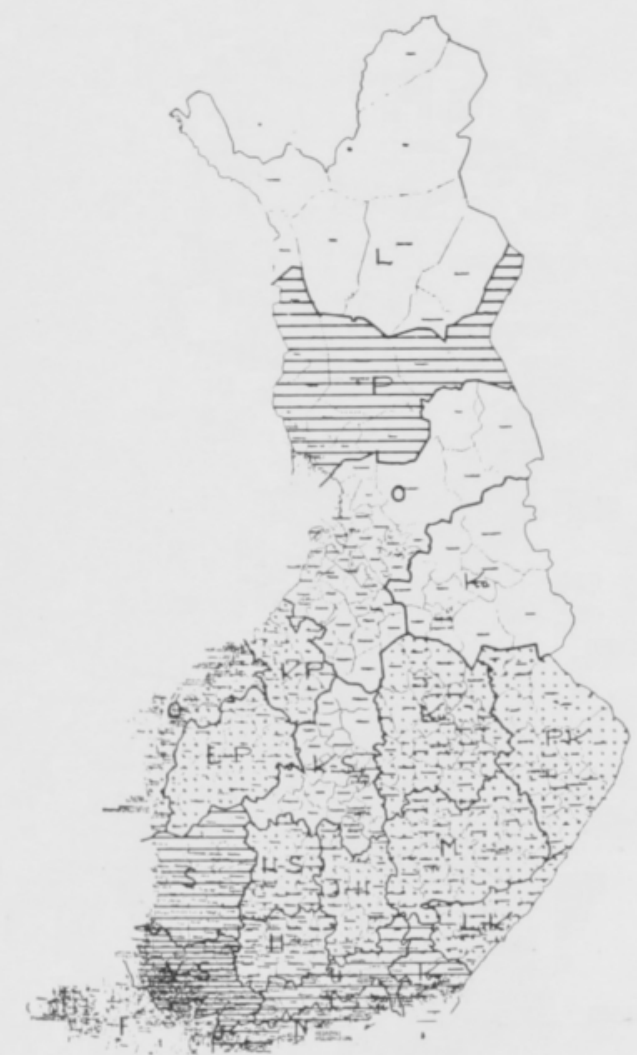

c. Tammiston aikainen Tammisto Early

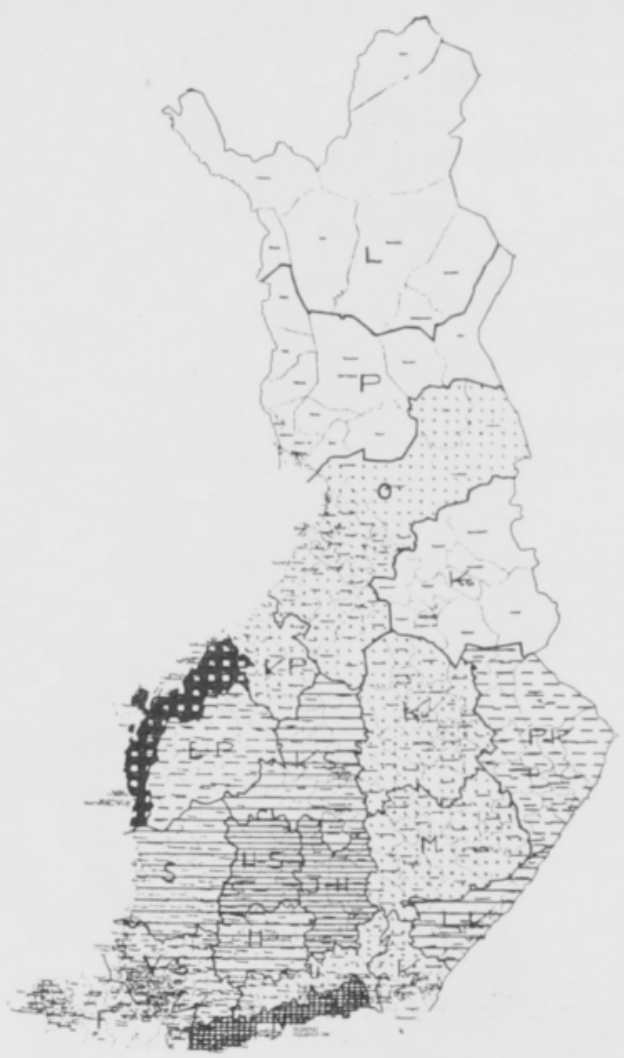

b. Ben Lomond

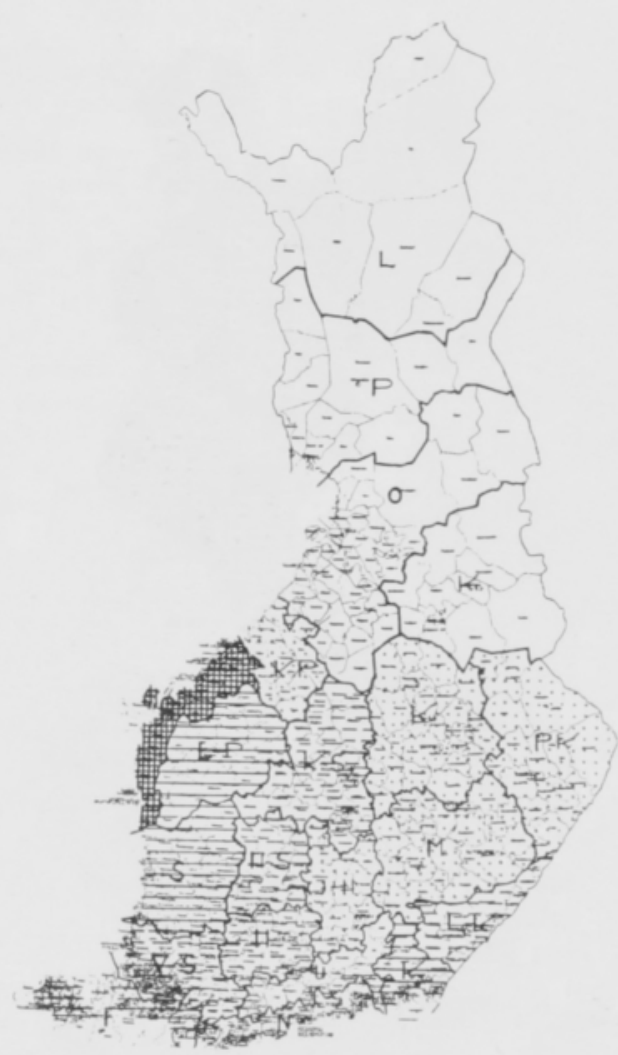

d. Iso skotlantilainen Great Scot

Piirros 3. a) Magnum bonumin, b) Ben Lomondin, c) Tammiston aikaisen ja d) Ison Skotlantilaisen viljelyalat \%:issa perunan koko viljelyalasta maanviljelysseuroittain vuonna 1950. (Vrt. karttaselostukseen piirroksessa 4 .)

Fig. 3. Percentages of the potato area under varieties a) Magnum bonum, b) Ben Lomond, c) Tammisto Early and d) Great Scot according to agricultural societies in 1950. (Obs. the notes in the Fig. 4.) 


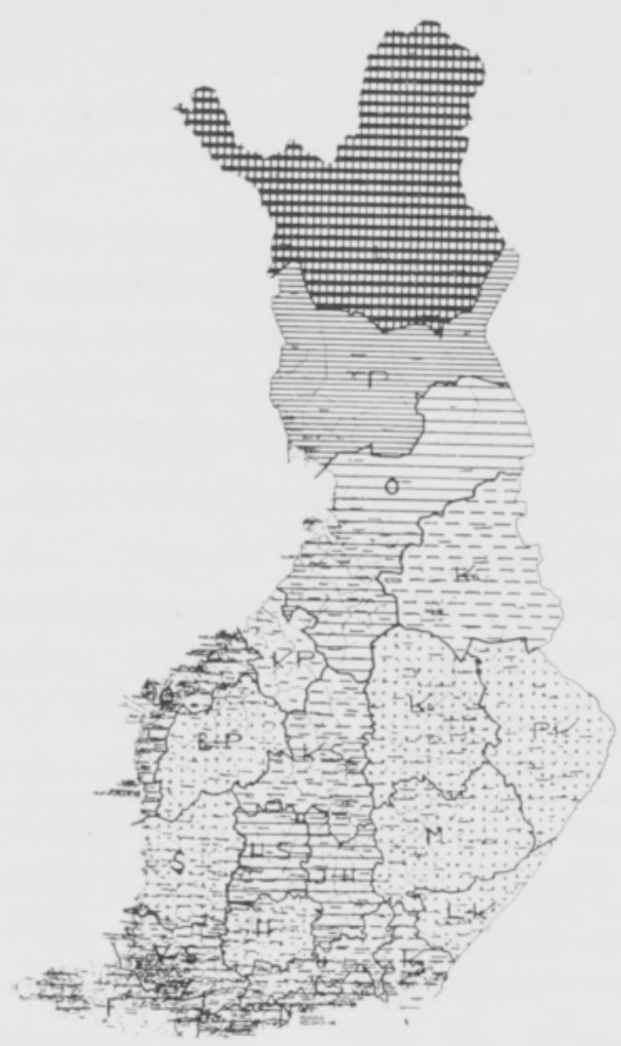

a. Puritaani Puritan

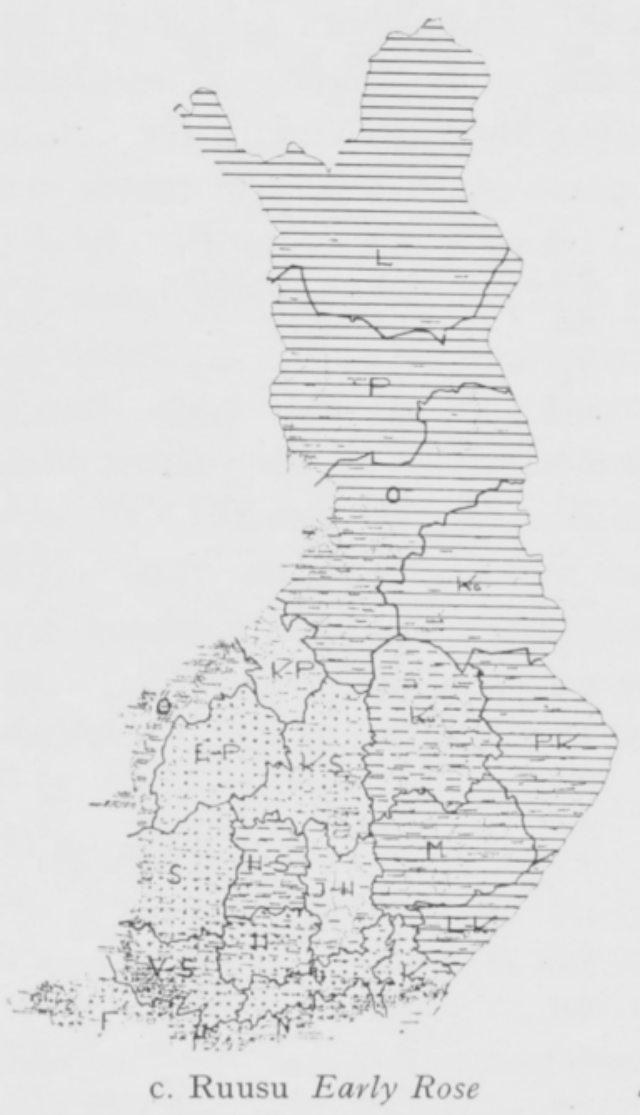

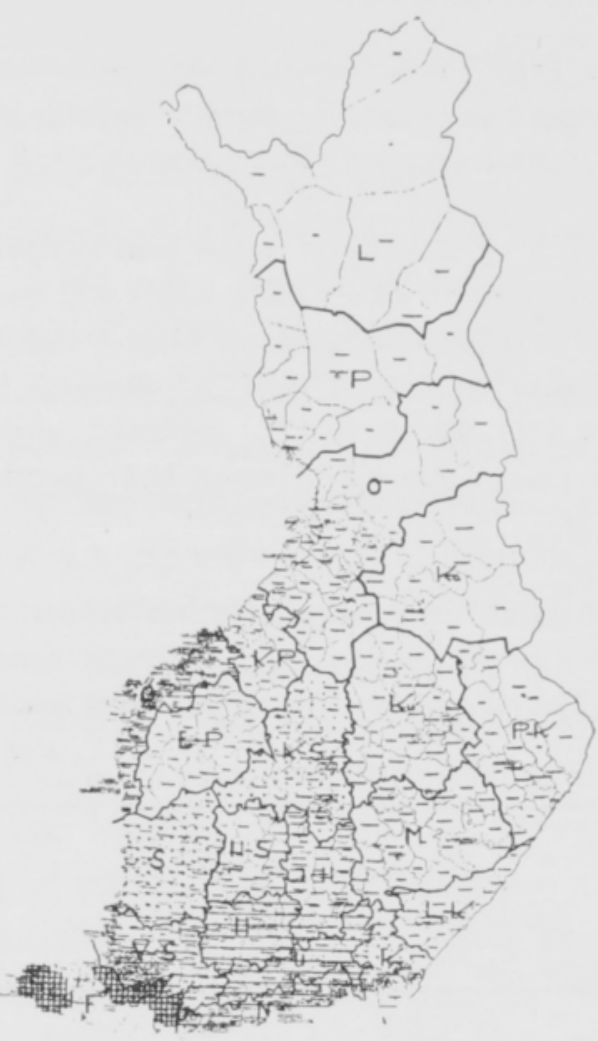

b. Majestic

Viljelyalasta From the cultivated area $\%$

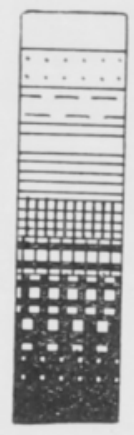

ei esiinny nothing

$0.0-0.9$

$1.0-1.9$

$2.0-3.9$

$4.0-5.9$

$6.0-7.9$

$8.0-9.9$

$10.0-14.9$

$15.0-19.9$

$20.0-24.9$

$25.0-$

$\mathrm{K}$ arttaseloste Mapnotes

Piirros 4. a) Puritanin, b) Majesticin ja c) Ruusun viljelyalat $\%$ :issa perunan koko viljelyalasta maanviljelysseuroittain vuonna 1950 .

Fig. 4. Percentages of the potato area under varieties a) Puritan b) Majestic and c) Early Rose according to agricultural societies in 1950. 
12. Iso skotlantilainen, Great Scot (taul. 1, piirros $3 \mathrm{~d}$ ). Tätä lajiketta viljellään runsaimmin Pohjanmaan ruotsalaisella rannikkoalueella ja Kymenlaaksossa sekä Ahvenanmaalla ja Turun saaristoalueella. Muualla on sen viljely yleensä alle $2.0 \%$ viljelyalasta. Koko maan peruna-alasta on sen osuus $1.3 \%$.

Muista lajikkeista on ainoastaan Puritaanin (piirros 4 a) viljelyala yli $1.0 \%$ perunan koko alasta. Muiden lajikkeiden viljelyala on alle $1.0 \%$ maan koko peruna-alasta. Näistä huomattavammin esiintyneet ovat tärkeysjärjestyksessä: Majestic $(0.9 \%$, piirros 4 b), Ruusu (Early Rose) $(0.9 \%$, piirros 4 c). Alfa $(0.7 \%)$, Ostbote $(0.5 \%)$, Heinäkuu (Juli) $(0.4 \%)$, Pepo $(0.3 \%)$, Deodara $(0.2 \%)$, Nuutti (Frühnudel) $(0.1 \%)$, Bintje $(0.1 \%$ ) ja Siikli (Sieglinde) $(0.1 \%)$. Muiden nimeltä mainittujen lajikkeiden osuus on jäänyt alle $0.1 \%$ maan koko peruna-alasta.

Taulukko 2. Tärkeimpien perunalajikkeiden viljelylaajuus eri kokoisilla viljelmillä v. 1950 \%:issa vastaavasta perunan koko viljelyalasta.

Table 2. The percentages of the potato area under the most important varieties of potato according to the farm size classes in 1950.

\begin{tabular}{|c|c|c|c|c|c|}
\hline \multirow{2}{*}{$\begin{array}{l}\text { Lajike } \\
\text { Variety }\end{array}$} & \multicolumn{4}{|c|}{$\begin{array}{l}\text { Viljelmän suuruusluokittain \% } \\
\text { Farm size classes }\end{array}$} & \multirow{2}{*}{$\begin{array}{c}\text { Keskimäärin } \\
\text { Average } \\
\%\end{array}$} \\
\hline & $2-4.99$ & $5-9.99$ & $10-24.99$ & $25-\omega$ & \\
\hline Alfa $\ldots \ldots \ldots \ldots \ldots \ldots \ldots \ldots$ & 0.3 & 0.5 & 0.5 & 2.0 & 0.7 \\
\hline Ben Lomond $\ldots \ldots \ldots \ldots \ldots \ldots \ldots \ldots$ & 1.7 & 2.2 & 2.2 & 2.8 & 2.5 \\
\hline 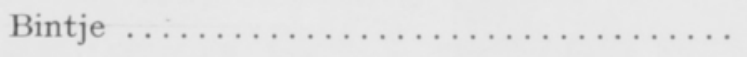 & 0.1 & 0.1 & 0.1 & 0.2 & 0.1 \\
\hline Deodara $\ldots . . \ldots \ldots \ldots \ldots \ldots \ldots$ & 0.1 & 0.1 & 0.2 & 0.1 & 0.2 \\
\hline Eigenheimer $\ldots \ldots \ldots \ldots \ldots \ldots \ldots \ldots$ & 6.4 & 7.2 & 9.5 & 6.0 & 7.7 \\
\hline Eldorado $\quad \ldots \ldots \ldots \ldots \ldots \ldots \ldots \ldots$ & 2.6 & 3.2 & 3.7 & 3.0 & 3.2 \\
\hline Heinäkuu, July $\ldots \ldots \ldots \ldots \ldots \ldots \ldots \ldots \ldots$ & 0.4 & 0.6 & 0.3 & 0.3 & 0.4 \\
\hline Iso skotlantilainen, Great Scot $\ldots \ldots \ldots \ldots$ & 1.0 & 1.3 & 1.4 & 1.7 & 1.3 \\
\hline Kuningas Yrjö, King George $\ldots \ldots \ldots \ldots \ldots$ & 2.3 & 3.8 & 7.0 & 14.9 & 6.4 \\
\hline Laivaperuna, Obenwälder Blaue $\quad \ldots \ldots \ldots \ldots$ & 2.8 & 3.4 & 4.1 & 2.1 & 3.3 \\
\hline Magnum bonum $\quad \ldots \ldots \ldots \ldots \ldots \ldots \ldots$ & 1.9 & 3.0 & 3.7 & 4.3 & 3.2 \\
\hline Majestic $\ldots \ldots \ldots \ldots \ldots \ldots \ldots \ldots$ & 0.6 & 0.7 & 1.2 & 0.8 & 0.9 \\
\hline Nuutti, Frühnudel. . . . . . . . . . . . . . . & - & $(0.0)$ & 0.1 & 0.6 & 0.1 \\
\hline Ostbote $\quad \ldots \ldots \ldots \ldots \ldots \ldots \ldots \ldots \ldots$ & 0.1 & 0.4 & 0.4 & 1.7 & 0.5 \\
\hline Parnassia ..................... & - & - & $(0.0)$ & - & $(0.0)$ \\
\hline Paulin peruna, Paul Wagner $\ldots \ldots \ldots \ldots \ldots$ & 4.5 & 5.4 & 6.8 & 7.4 & 6.1 \\
\hline Реро....................... & 0.2 & 0.1 & 0.2 & 0.8 & 0.3 \\
\hline Puritaani, Puritan $\quad \ldots \ldots \ldots \ldots \ldots \ldots$ & 1.3 & 1.2 & 1.5 & 0.7 & 1.2 \\
\hline Ruusu, Early Rose $\ldots \ldots \ldots \ldots \ldots \ldots$ & 1.6 & 1.3 & 0.5 & 0.1 & 0.9 \\
\hline Ruusulehti, Rosafolia $\ldots \ldots \ldots \ldots \ldots \ldots$ & 7.4 & 10.3 & 13.2 & 19.7 & 12.3 \\
\hline Siikli, Sieglinde $\ldots \ldots \ldots \ldots \ldots \ldots \ldots$ & $(0.0)$ & $(0.0)$ & $(0.0)$ & 0.2 & 0.1 \\
\hline Tammiston aikainen, Tammisto Early ..... & 1.0 & 1.1 & 1.3 & 2.1 & 1.3 \\
\hline Upto, Uptodate $\ldots \ldots \ldots \ldots \ldots \ldots \ldots \ldots$ & 6.0 & 6.2 & 4.6 & 2.9 & 5.0 \\
\hline Vesijärvi, Harbinger $\ldots \ldots \ldots \ldots \ldots \ldots \ldots$ & 9.6 & 8.9 & 9.6 & 7.6 & 9.1 \\
\hline Maatiaiset, Local $\ldots \ldots \ldots \ldots \ldots \ldots \ldots$ & 7.6 & 4.4 & 2.2 & 0.8 & 3.6 \\
\hline Sekalaiset, Mixed varieties $\ldots \ldots \ldots \ldots \ldots$ & 16.7 & 13.0 & 8.2 & 5.3 & 10.7 \\
\hline Muut, Others $\ldots \ldots \ldots \ldots \ldots \ldots \ldots \ldots$ & 8.1 & 8.0 & 7.9 & 6.5 & 7.7 \\
\hline \multirow[t]{2}{*}{ Tuntemattomat, Unknown $\ldots \ldots \ldots \ldots \ldots \ldots$} & 15.7 & 13.6 & 9.6 & 5.4 & 11.2 \\
\hline & 100.0 & 100.0 & 100.0 & 100.0 & 100.00 \\
\hline Perunan viljelyala, ha Area under potato, ha & 14662 & 22780 & 29080 & 12402 & 78924 \\
\hline
\end{tabular}


Esitetyn perusteella voidaan todeta, että tunnettujen lajikkeiden viljelyala on maan eteläpuoliskon maanviljelysseuroissa suhteellisesti suurempi kuin maan itä- ja pohjoisosissa. Etelä-Suomen maanviljelysseuroissa käytetään yleisemmin tunnettuja ja puhtaita lajikkeita siemenenä kuin pohjoisempana. Eri maanviljelysseurojen välisiä suhdelukuja verrattaessa voidaan niissä kuitenkin havaita melkoisia eroavaisuuksia (vrt. taul. 1), mikä seikka ainakin osaksi viittaa leväperäisyyteen, jota on esiintynyt ko. lomakkeita viljelmillä täytettäessä silloin, kun kysymyksessä on ollut lajikkeeltaan epäselvät tai epävarmat tai tuntemattomat perunaviljelykset. Maatiaisiksi merkityt lajikkeet ovat saattaneet olla useamman lajikkeen sekoituksia tai kuulua johonkin muista lajikkeista ja päinvastoin. Ei vain ole tunnettu lajiketta. Lajiketiedustelun tuloksia tarkasteltaessa ei liene paikallaan käsitellä maatiaisiksi, sekalaisiksi, muiksi ja tuntemattomiksi merkittyjä lukuja erikseen, vaan summana, koska ei varmuudella voida eritellä näiden lukujen sisältöä. Tämänkaltainen menettely on oikeampi senkin vuoksi, että juuri tähän ryhmään kokonaisuutena on kiinnitettävä lajikevalinnan ohjauksessa erityistä huomiota.

Edellä käsitelty aineisto on ryhmitelty myös siten, että voidaan suorittaa eri lajikkeiden viljelylaajuuden vertailuja eri kokoisilla viljelmillä. Tätä koskevat tulokset on esitetty taulukossa 2. Viljelmät on jaettu neljään suuruusluokkaan pelto-alan perusteella: $2-4.99,5-9.99,10-24.99$ ja 25 ha tai enemmän peltoa käsittävät viljelmät. Yleisenä piirteenä voidaan todeta, että pienillä tiloilla on tunnettujen lajikkeiden käyttö vielä huomattavan vähäistä, sillä $2-4.99$ ha:n viljelmillä saadusta perunasadosta on vain hieman yli puolet eli $51.9 \%$ lajikkeeltaan tunnettua. Viljelmänkoon suuretessa tunnettujen lajikkeiden käyttö kasvaa. Niinpä se seuraavassa suuruusluokassa on $61.0 \%$, sitä seuraavassa suuruusluokassa $72.1 \%$ ja yl i25 ha:n viljelmillä jopa $82.0 \%$. Lajikevalinnan ohjauksen tulisi näin ollen kohdistua erityisen voimakkaana pienien viljelmien omistajiin.

Taulukosta 2 voidaan todeta edellisen lisäksi, että eräitä lajikkeita viljellään suhteellisesti enemmän suurilla viljelmillä kuin pienillä. Eräät lajikkeet esiintyvät taas yleisemmin pienillä kuin suuremmilla viljelmillä. Esimerkiksi Ruusulehti, Kuningas Yrjö, Paulin peruna ja Magnum bonum esiintyvät suhteellisesti paljon yleisemmin suuremmilla viljelmillä kuin pienillä, kun taas esimerkiksi Vesijärven ja Upton kohdalla tilanne on päinvastainen. Osittaisena syynä tähän on se, että Vesijärven ja Upton viljelyalue on pienten viljelmien aluetta, Itä- ja Pohjois-Suomea, kun taas esimerkiksi Ruusulehden viljelyalue sattuu pääasiassa alueelle, jossa viljelmät ovat keskimäärin suurempia. Lajikevalinta näyttelee kuitenkin tässäkin jakautumisessa huomattavaa osaa.

\section{Loppupäätelmät}

Vuoden 1950 maatalouslaskennan yhteydessä suoritettu otantatiedustelu perunalajikkeiden viljelylaajuuksista osoittaa, että myöskin Suomessa viljelty perunalajikkeisto on varsin kirjava, ja että huomattavan suurilla aloilla vielä viljellään tuntemattomia, sekalaisia ja maatiaislajikkeita. Yleisimmin viljelty perunalajikkeemme on Ruusulehti, mutta senkään viljelyala ei ole ollut suurempi kuin 
1/8 maan koko peruna-alasta. Selvitettyjen lajikkeiden hallussa oleva viljelyala on ollut $2 / 3$ koko peruna-alasta, joten kolmanneksella viljelyalasta vielä viljellään sekalaisia $(10.7 \%)$, tarkemmin määrittelemättömiä tai tuntemattomia $(18.9 \%)$ ja maatiaisia $(3.6 \%$ ). Vastaisen lajikeohjauksen tulisi epäilemättä kohdistua juuri näiden ryhmien osuuden pienentämiseen. Niinikään olisi pyrittävä supistamaan myös vanhojen heikkosatoisten perunalajikkeiden viljelyä. Edelleen olisi lajikevalintaohjaus kohdistettava erityisesti pienikokoisiin viljelmiin, joiden perunalajikkeisto kaipaa eniten uusimista, kuten taulukosta 2 voidaan todeta. Toiselta puolen on lajikeohjausta suunniteltaessa ja toteutettaessa muistettava, että valtaosa maan perunasadosta tuotetaan yli 10 ha peltoa sisältäviltä viljelmiltä. Tulevaa lajikeohjausta ja sen tuloksellisuuden seuraamista silmällä pitäen tullaan vastaisuudessakin panemaan toimeen esitetynlaisia lajiketiedusteluja. Suunnitelmien mukaan tapahtuisivat tiedustelut joka viides vuosi.

\section{KIRJALLISUUTTA}

(1) Hagberth, N. O. 1951. Potatissorterna i Sverige. Uppsala.

(2) PaAtela, Juhani 1953. Tärkeimmät viljalajikkeemme ja niiden viljelylaajuus. Acta Agralia Fennica, 80,1 .

(3) SAKsA, P. J. 1952. Peltomaiden maalajisuhteista. Koetoiminta ja Käytäntö, 11.

R E F E R A T:

THE EXTENT AND THE REGIONS OF THE CULTIVATION OF POTATO VARIETIES

IN FINLAND

P. J. SAKSA

Statistical Office on the Board of Agriculture, Helsinki

The random survey of the arable land area under different varieties of potato, made in connection with the 1950 Agricultural Census indicates that in Finland, as elsewhere, a large number of potato varieties are cultivated and that considerable areas are still planted with unknown, miscellaneous and local varieties. Our most widely cultivated potato variety is Ruuusulehti (Rosafolia), but the area under this variety was only $1 / 8$ of the whole potato area of the country. The area under determined potato varieties was $2 / 3$ of the whole potato area, one third thus being cultivated with miscellaneous $(10,7 \%)$, incompletely determined or unknown $(18,9 \%)$ and local $(3,6 \%)$ varieties, In future, variety guidance should undoubtedly be directed to diminishing the proportion of these latter groups. Efforts should likewise be made to reduce the growing of old potato varieties with a poor crop. Further guidance regarding variety selection should especially be concentrated upon small farms, where potato varieties are in most need of renewal, as table 2 indicates. Otherwise in planning and giving variety guidance, it must be remembered that the bulk of the country's potato crop is produced by farms with an arable land area of more than 10 hectares. With a view to future variety guidance and to observing its effect, continued surveys similar to the present will be undertaken. It is planned to make such surveys every fifth year. 